\title{
Effect of land use on the composition, diversity and abundance of insects drifting in neotropical streams
}

\author{
B. C. G. Gimenez ${ }^{a}$, F. A. Lansac-Tôha ${ }^{a}$ and J. Higuti ${ }^{a}$ \\ ${ }^{a}$ Núcleo de Pesquisas em Limnologia, Ictiologia e Aquicultura, Programa de Pós-graduação em Ecologia de Ambientes \\ Aquáticos Continentais, Departamento de Biologia, Universidade Estadual de Maringá - UEM, \\ Av. Colombo, 5790, CEP 87020-900, Maringá, PR, Brazil \\ *e-mail: barbaracggimenez@gmail.com
}

Received: March 12, 2014 - Accepted: September 28, 2014 - Distributed: November 30, 2015

(With 2 figures)

\begin{abstract}
Streams may exhibit differences in community structure of invertebrate drift, which may be a reflex of variation in environmental factors, able to change in conditions of anthropogenic interventions. The aim of this study was to analyze the composition, diversity and abundance of insects drifting in two neotropical streams under different land use and to identify the environmental factors involved in determining such patterns. 54 taxa of aquatic insects were identified in urban and rural streams. The results indicated significant differences in species composition due to the replacement of specialist species by generalist species in the urban stream. Higher diversity of taxa was recorded in the rural stream, with high levels of dissolved oxygen and high water flow, which favored the occurrence of sensitive groups to environmental disturbances, such as Ephemeroptera, Plecoptera, Trichoptera and Coleoptera taxa, that living mainly in clean and well oxygenated waters. On the other hand, a higher density of insects drifting, especially Chironomidae, was observed in the urban stream, where high values of $\mathrm{pH}$, electrical conductivity and nitrogen were observed. These larvae are able to explore a wide range of environmental conditions, owing to their great capacity for physiological adaptation. Despite observing the expected patterns, there were no significant differences between streams for the diversity and abundance of species. Thus, the species composition can be considered as the best predictor of impacts on the drifting insect community.
\end{abstract}

Keywords: aquatic invertebrates, urbanization, human impact, lotic environments.

\section{Efeito do uso do solo sobre a composição, diversidade e abundância de insetos à deriva em riachos neotropicais}

\begin{abstract}
Resumo
Riachos podem exibir diferenças na estrutura das comunidades de invertebrados à deriva, o que pode ser um reflexo da variação nos fatores ambientais, capazes de se alterar em condições de intervenções antrópicas. O objetivo deste trabalho foi analisar a composição, diversidade e abundância de insetos à deriva em dois riachos neotropicais sob diferentes usos do solo, além de identificar os fatores ambientais intervenientes na determinação de tais padrões. Foram registrados 54 táxons de insetos aquáticos nos riachos urbano e rural. Os resultados evidenciaram diferenças significativas na composição de espécies, devido à substituição de espécies especialistas por espécies generalistas no riacho urbano. Maior diversidade de táxons foi registrada no riacho rural, com altos níveis de oxigênio dissolvido e elevado fluxo hídrico, que favoreceram a ocorrência de grupos sensíveis a perturbações ambientais, como táxons das ordens Ephemeroptera, Plecoptera, Trichoptera e Coleoptera, que vivem principalmente em águas limpas e bem oxigenadas. Por outro lado, maior densidade de insetos a deriva, especialmente Chironomidae, foi observada no riacho urbano, onde foram registrados elevados valores de $\mathrm{pH}$, condutividade elétrica e nitrogênio. Estas larvas são capazes de explorar uma vasta gama de condições ambientais, consequência da sua grande capacidade de adaptação fisiológica. Apesar de ter encontrado os padrões esperados, não foram contatadas diferenças significativas na diversidade e abundância de espécies entre os riachos. Assim, a composição de espécies pode ser considerada como melhor preditora de impactos sobre a comunidade de insetos à deriva.
\end{abstract}

Palavras-chave: invertebrados aquáticos, urbanização, impacto antrópico, ambientes lóticos. 


\section{Introduction}

Lotic ecosystems, such as streams, are those with unidirectional and continuous water flow responsible for maintaining several process, such as organic matter transport, sediment deposition and formation of longitudinal gradients within drainage basins (Vannote et al., 1980). These factors, in addition to changes in current velocity, may have direct or indirect influence on local biological communities (Ward et al., 1995). The fluvial continuum of these environments allows the dispersion of immature stages of aquatic invertebrates, and thus, the colonization of river reaches downstream from their original habitats (Callisto and Goulart, 2005).

This dispersion process occurs through downstream transport of invertebrates suspended in the water column, in a very common phenomenon in stream ecosystems, known as drift (Brittain and Eikeland, 1988). Drift strongly influences invertebrate community structure and composition (Hansen and Closs, 2007) and is an important aspect in the study of these organisms, because besides being related to secondary production in water bodies, it is also an important source of food for fish and an effective way for some aquatic organisms to colonize new areas (Principe and Corigliano, 2006; Castro et al., 2013). Generally, individuals suspended in drift are those that live in or on the substrate, known as benthic invertebrates (Elliott, 2008). Several authors have reported that there is no pattern of taxonomic composition, however among organisms derived from benthic communities, immature forms of insects represent the dominant group in the composition of the drift (Waters, 1972).

In normal flow conditions, near bed, shear forces occasionally dislodge individuals, causing the termed constant, involuntary or passive drift (Waters, 1972). However, drift can be caused and influenced by a number of factors, both biotic as abiotic. Biotic factors are usually related to behavioral or voluntary drift, also known as active drift, which occurs as a result of some normal behavioral characteristic of the animal, in response to changes in one or more biotic factors (Waters, 1965). On the other hand, the term "catastrophic drift" is used to describe the marked increase in drift that occurs as a result of floods, pollution events or others physicochemical disturbances (Waters, 1965). Accordingly, when there are drastic changes in abiotic variables, there may be an increase in the rates of drift and it becomes not only behavioral and/ or constant, but also catastrophic.

Water ecosystems are among the most affected by human activities, especially in urban areas, where there is a higher population and industrial concentration, generating solid and liquid waste (Meyer et al., 2005). Thus, aquatic environments serve as receptors for a wide variety of effluents, which in general alter the morphology of the channel and the hydrological regime (Júlio-Junior et al., 2005). In addition to the urbanization, agriculture is also an important human activity that affects water quality, because it culminates in an increased input of sediment, nutrients and pesticides, which, beyond water quality, also affect the habitat structure and biological community (Allan, 2004). Therefore, a gradient of environmental degradation, as the rural-urban, can affect differently the community, and the type and severity of the impact are determinants in the abundance, diversity and community composition (Moreno et al., 2009).

The aquatic insects, the richest and most abundant in aquatic communities, may be directly affected by the anthropogenic changes (Saulino et al., 2014). Thus, the distribution of this fauna is related to food availability, substrate type, and physical and chemical characteristics of water (Callisto et al., 2005), beyond the habits of the species and current velocity, which can act on the nature of the substrate, influencing the structure of the community (Resh and Rosenberg, 1984) and in turn the drift, considering that changes in limnological variables can lead to the catastrophic drift. In this context, this study aimed to analyze the composition, diversity and abundance of insects drifting in two neotropical streams under different land use (agriculture and urbanization) and to identify the environmental factors involved in determining such patterns.

We hypothesized that taxa composition is different between streams under different land use and that the urbanization leads to less diversity and a higher abundance of drifting insects. Based on these hypotheses, we expect the replacement of specialist by generalist species in urban stream, a higher diversity of drifting insects, and a greater abundance of drifting insects in the urban stream.

\section{Material and Methods}

\subsection{Study area}

The Pirapó River basin is located in northern Paraná State and inserted in the physiographic region of the Third Paraná Plateau. With a catchment area of approximately $5,076 \mathrm{~km}^{2}$, the Pirapó River covers an extension of $168 \mathrm{~km}$ to its mouth in the Paranapanema River, approximately $50 \mathrm{~km}$ from the city of Maringá, being responsible for the water supply of the municipality (SANEPAR, 2002). The climate in the region is Subtropical Humid Mesothermal, with average annual temperature of $20^{\circ} \mathrm{C}$, with dry winters and concentration of rainfall in the summer months (Kuhl et al., 2010).

In the area occupied by the basin, four distinct vegetation types may occur: the Seasonal Semideciduous Forest, the Mixed Rain Forest (Araucaria Forest), Natural Fields and fragments of Cerrado. The landscape of the basin is characterized by a mosaic of agriculture and urban development, especially in the metropolitan area of Maringá, which stands as an important agro-industrial center of the region, being the third most populous city in the Paraná State (IBGE, 2010).

We selected two second-order streams belonging to the Pirapó River basin. The Nazaré stream (232 24'04,64” S; $\left.51^{\circ} 58^{\prime} 03,57^{\prime} \mathrm{W}\right)$ is located in the urban perimeter, with $34.8 \%$ of impervious surfaces and $100 \%$ of urbanization, 
affected by storm sewer, domestic sewage and surface leaching. The Remo stream $\left(23^{\circ} 21^{\prime} 39,26^{\prime}\right.$ ' $\mathrm{S}$; $\left.52^{\circ} 01^{\prime} 02,48^{\prime \prime} \mathrm{W}\right)$ is located in rural area with $0.5 \%$ of impervious surfaces and $0.5 \%$ of urbanization, having agricultural effluents as a source of pollution (Kuhl et al., 2010; Cunico et al., 2012).

\subsection{Data collection}

Biological and limnological samples were collected in July 2007 and February 2008, in both neotropical streams. At each stream, we collected at three points along the longitudinal gradient (headwaters, middle and mouth).

The variables water temperature, dissolved oxygen, $\mathrm{pH}$ and electrical conductivity were measured in the field. Samples for determination of total nitrogen, total phosphorus, chemical and biochemical oxygen demand were analyzed by the Laboratory of Sanitation; oils and greases and concentrations of lead and mercury were analyzed by the Laboratory of Agrochemistry, both at the Universidade Estadual de Maringá (UEM). Values of water flow and river discharge were also measured; the values of water flow were obtained with an electronic flow meter and the river discharge calculated according to the equation $Q=A * v$, where $A$ represents the area of the vertical riverbed and $v$ the flow in $\mathrm{m}^{-\mathrm{s}^{-1}}$ (Hauer and Lamberti, 2007).

Aquatic insects were sampled in the morning. At each point, three samples were collected using a drift net (0.045 $\mathrm{m}^{2}$ area and mesh size 250 microns) coupled to a mechanical flowmeter, totaling nine samples in each stream, in each sampling period. The biological material was fixed in the field with formaldehyde $4 \%$ buffered with calcium carbonate. In the laboratory, samples were sorted under a stereoscopic microscope, and thereafter, the organisms were identified using Pes et al. (2005), Salles (2006), Trivinho-Strixino (2011) and Novaes et al. (2012).

\subsection{Data analysis}

A $t$-test for independent samples was used to check for significant differences in abiotic variables between urban and rural streams, using Statistica 7.1 (StatSoft Inc., 2005).

The filtered water volume in each sample was calculated by multiplying the area of the drift net by a constant $f$ $(0.026873)$ and a value $r$, which corresponds to the amount of water that passed through the net during the time spent in collecting (time constant). Then, the numerical density of drifting insects was estimated from the volume of water filtered in each sample, and expressed in individuals per cubic meter.

To analyze the variability of the drifting aquatic insect community ( $\beta$ diversity) between urban and rural streams, we performed a test of homogeneity of dispersion PERMDISP (Anderson et al., 2006). The test calculates a centroid for each type of stream, and determines the Bray-Curtis distance of each sampling site to the centroid. The higher the average of Bray-Curtis distances to the centroid, the greater is the dissimilarity in species composition, suggesting an increase in $\beta$ diversity. The significance $(p<0.05)$ of differences in beta diversity between streams was assessed with a permutation test of least squares residuals, using 999 permutations. This analysis was run using the R 3.0.1 software (R Development Core Team, 2008) through vegan package (Oksanen et al., 2013).

Richness and Shannon-Wiener diversity were measured to assess changes in the drifting aquatic insect community in urban and rural streams. The Shannon-Wiener diversity index (Magurran, 1988) was calculated according to the equation $H^{\prime}=-\sum(n i / N) \log (n i / N)$, where $n i=$ number of individuals in the $i$ th species and $N=$ total number of individuals sampled. In order to test possible significant differences in richness (S) (total number of taxa or alfa diversity), density (D) and Shannon-Wiener diversity (H') between urban and rural streams, univariate analyses of variance (ANOVA) were performed. When the assumption of homoscedasticity for the parametric analyses of variance was not met, we used the nonparametric Kruskal-Wallis test. The richness and Shannon-Wiener diversity were calculated in R 3.0.1 software (R Development Core Team, 2008), through BiodiversityR package (Kindt and Coe, 2005) and analyses of variance were run in Statistica 7.1 (StatSoft Inc., 2005).

\section{Results}

Significant differences were detected to $\mathrm{pH}(\mathrm{t}=5.04$; $\mathrm{p}<0.001)$, electrical conductivity $(\mathrm{t}=13.22 ; \mathrm{p}<0.001)$ and nitrogen $(\mathrm{t}=3.40 ; \mathrm{p}<0.005)$, with higher values in the urban stream, while higher oxygenation $(\mathrm{t}=-2.72$; $\mathrm{p}<0.05)$, mercury $(\mathrm{t}=-2.37 ; \mathrm{p}<0.05)$ and flow $(\mathrm{t}=-3.60$; $\mathrm{p}<0.005$ ) were recorded in the rural stream (Table 1).

We identified 54 taxa of aquatic insects, of the orders Ephemeroptera, Odonata, Plecoptera, Hemiptera,

Table 1. Mean values and standard error of abiotic variables of the urban and rural streams.

\begin{tabular}{|c|c|c|}
\hline & \multicolumn{2}{|c|}{ Stream } \\
\hline & Urban & Rural \\
\hline Water temperature $\left({ }^{\circ} \mathrm{C}\right)$ & $18.47 \pm 3.27$ & $18.87 \pm 2.76$ \\
\hline $\begin{array}{l}\text { Dissolved oxygen } \\
\left(\mathrm{mg} \cdot \mathrm{L}^{-1}\right)\end{array}$ & $8.25 \pm 0.48$ & $8.62 \pm 0.31$ \\
\hline $\mathrm{pH}$ & $7.26 \pm 0.28$ & $6.80 \pm 0.27$ \\
\hline $\begin{array}{l}\text { Electrical conductivity } \\
\left(\mu \mathrm{S} . \mathrm{cm}^{-1}\right)\end{array}$ & $287.50 \pm 55.42$ & $112.40 \pm 9.35$ \\
\hline Phosphorus (mg. $\mathrm{L}^{-1}$ ) & $0.08 \pm 0.06$ & $0.09 \pm 0.07$ \\
\hline Nitrogen (mg. $\left.\mathrm{L}^{-1}\right)$ & $7.67 \pm 2.14$ & $4.52 \pm 3.29$ \\
\hline $\begin{array}{l}\text { Chemical oxygen } \\
\text { demand }\left(\mathrm{mg} . \mathrm{L}^{-1}\right)\end{array}$ & $3.89 \pm 5.05$ & $8.47 \pm 8.84$ \\
\hline $\begin{array}{l}\text { Biochemical oxygen } \\
\text { demand }\left(\mathrm{mg} . \mathrm{L}^{-1}\right)\end{array}$ & $1.36 \pm 1.95$ & $1.64 \pm 0.89$ \\
\hline $\begin{array}{l}\text { Oils and greases } \\
\left(\mathrm{mg} \cdot \mathrm{L}^{-1}\right)\end{array}$ & $0.20 \pm 0.17$ & $0.10 \pm 0.23$ \\
\hline Lead (mg. $\left.\mathrm{L}^{-1}\right)$ & $0.02 \pm 0.02$ & $0.01 \pm 0.01$ \\
\hline Mercury (mg. $\mathrm{L}^{-1}$ ) & $0.001 \pm 0.001$ & $0.002 \pm 0.0008$ \\
\hline Flow $\left(\mathrm{m} . \mathrm{s}^{-1}\right)$ & $0.15 \pm 0.07$ & $0.23 \pm 0.06$ \\
\hline Discharge $\left(\mathrm{m}^{3} \cdot \mathrm{s}^{-1}\right)$ & $0.05 \pm 0.05$ & $0.05 \pm 0.01$ \\
\hline
\end{tabular}


Coleoptera, Trichoptera, Lepidoptera and Diptera, in both streams; 33 taxa in the urban stream and 39 taxa in the rural stream (Table 2). Terrestrial insects and exuviae were not considered.

The PERMIDISP analysis revealed significant differences in the variability of species composition ( $\beta$ diversity) between urban and rural streams $(F=4.36$; $\mathrm{p}=0.04$ ), further suggesting a greater dissimilarity in species composition in the urban stream. The highest average distance to the centroid was recorded in the urban stream (centroid distance $=0.64)$ compared to the rural stream (centroid distance $=0.61)($ Figure 1$)$.

Higher mean values of richness (Figure 2A) and density (Figure 2B) were verified in the urban stream, while the

Table 2. Composition and mean density (ind. $\mathrm{m}^{-3}$ ) of drifting insects recorded in the urban and rural streams.

\begin{tabular}{|c|c|c|c|c|}
\hline \multicolumn{3}{|c|}{ Taxa } & \multicolumn{2}{|c|}{ Stream } \\
\hline Order & Family & Species & Urban & Rural \\
\hline \multirow[t]{6}{*}{ Ephemeroptera } & Baetidae & Americabaetis sp. & $1.08 \pm 2.93$ & $0.22 \pm 0.38$ \\
\hline & & Baetodes sp. & $3.08 \pm 6.02$ & \\
\hline & & Camelobaetidius sp. & & $0.03 \pm 0.12$ \\
\hline & Leptohyphidae & Leptohyphes sp. & & $0.06 \pm 0.15$ \\
\hline & & Traverhyphes sp. & $0.03 \pm 0.08$ & $0.44 \pm 0.52$ \\
\hline & Leptophlebiidae & Farrodes sp. & & $0.04 \pm 0.10$ \\
\hline \multirow[t]{2}{*}{ Odonata } & Coenagrionidae & & $0.27 \pm 1.05$ & \\
\hline & Libellulidae & & $0.12 \pm 0.42$ & $0.02 \pm 0.06$ \\
\hline Plecoptera & Perlidae & Anacroneuria ofaye Froehlich, 2007 & & $0.05 \pm 0.11$ \\
\hline Hemiptera & & & $0.46 \pm 0.47$ & $0.01 \pm 0.04$ \\
\hline \multirow[t]{5}{*}{ Coleoptera } & Lampyridae & & & $0.02 \pm 0.09$ \\
\hline & Hydrophilidae & & $0.17 \pm 0.57$ & \\
\hline & Elmidae & Heterelmis sp. & & $0.19 \pm 0.32$ \\
\hline & & Hexacylloepus sp. & & $0.03 \pm 0.12$ \\
\hline & & Macrelmis sp. & & $0.03 \pm 0.09$ \\
\hline \multirow[t]{7}{*}{ Trichoptera } & Hydropsychidae & Leptonema sp. & $0.09 \pm 0.22$ & $0.04 \pm 0.13$ \\
\hline & & Smicridea sp. & $0.50 \pm 1.14$ & $0.15 \pm 0.32$ \\
\hline & Hydroptilidae & Alisotrichia sp. & $0.19 \pm 0.40$ & \\
\hline & & Neotrichia sp. & $0.01 \pm 0.02$ & $0.04 \pm 0.10$ \\
\hline & Philopotamidae & Chimarra sp. & & $0.02 \pm 0.09$ \\
\hline & Leptoceridae & Oecetis sp. & & $0.02 \pm 0.09$ \\
\hline & Glossosomatidae & & & $0.17 \pm 0.23$ \\
\hline Lepidoptera & & & $0.13 \pm 0.29$ & $0.01 \pm 0.05$ \\
\hline \multirow[t]{31}{*}{ Diptera } & & & $0.83 \pm 1.74$ & $0.09 \pm 0.18$ \\
\hline & Ceratopogonidae & & $0.07 \pm 0.16$ & \\
\hline & Chironomidae & $\begin{array}{l}\text { Chironomus reissi Correia and Trivinho- } \\
\text { Strixino, } 2007\end{array}$ & $0.01 \pm 0.03$ & \\
\hline & & Endotribelos cf. hespe & $0.30 \pm 0.72$ & $0.06 \pm 0.12$ \\
\hline & & Lauterborniella sp. & & $0.18 \pm 0.39$ \\
\hline & & Polypedilum gr. fallax & $1.64 \pm 3.11$ & $0.03 \pm 0.11$ \\
\hline & & Polypedilum sp.1 & $0.01 \pm 0.04$ & \\
\hline & & Polypedilum sp.4 & $13.19 \pm 28.94$ & $0.10 \pm 0.22$ \\
\hline & & Polypedilum sp.5 & $0.12 \pm 0.33$ & \\
\hline & & Rheotanytarsus sp. & $0.35 \pm 0.57$ & $0.14 \pm 0.25$ \\
\hline & & Stempellina sp. & & $0.06 \pm 0.13$ \\
\hline & & Tanytarsus sp. & & $0.01 \pm 0.06$ \\
\hline & & Corynoneura sp.1 & & $0.01 \pm 0.04$ \\
\hline & & Corynoneura sp.2 & $0.07 \pm 0.27$ & $0.27 \pm 0.72$ \\
\hline & & Corynoneura sp. 3 & $0.24 \pm 0.54$ & $0.04 \pm 0.09$ \\
\hline & & Onconeura sp. & $0.65 \pm 1.70$ & $0.25 \pm 0.45$ \\
\hline & & Thienemanniella sp. & $0.50 \pm 0.93$ & \\
\hline & & Cricotopus sp.1 & $0.19 \pm 0.40$ & \\
\hline & & Cricotopus sp.2 & $0.14 \pm 0.24$ & $0.04 \pm 0.14$ \\
\hline & & Limnophyes sp. & $0.04 \pm 0.14$ & \\
\hline & & Nanocladius sp. & $0.07 \pm 0.20$ & \\
\hline & & Rheocricotopus sp. & & $0.15 \pm 0.22$ \\
\hline & & Fittkauimyia sp. & & $0.01 \pm 0.04$ \\
\hline & & Ablabesmyia (Karelia) & & $0.03 \pm 0.08$ \\
\hline & & Labrundinia sp. & & $0.01 \pm 0.05$ \\
\hline & & Larsia sp. & $0.67 \pm 1.38$ & \\
\hline & & Pentaneura sp. & & $0.07 \pm 0.21$ \\
\hline & & gr. Thienemannimyia & $0.01 \pm 0.04$ & \\
\hline & Empididae & & $0.14 \pm 0.36$ & \\
\hline & Simuliidae & & $1.43 \pm 2.56$ & $1.17 \pm 2.31$ \\
\hline & Psychodidae & & & $0.10 \pm 0.40$ \\
\hline
\end{tabular}




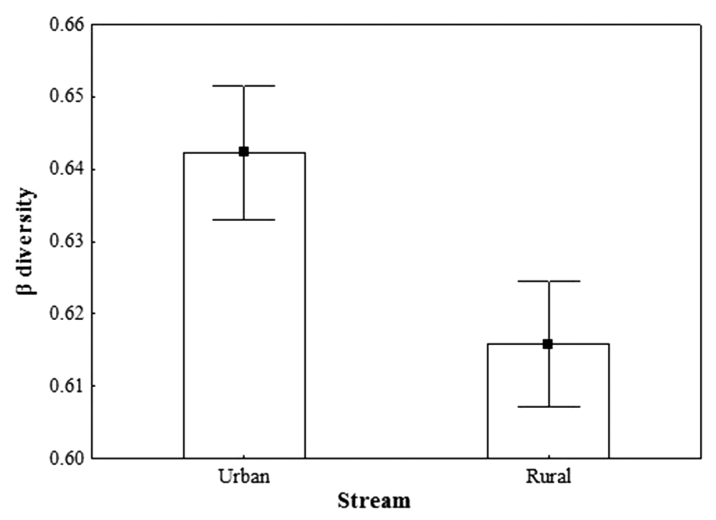

Figure 1. Mean values and standard error of $\beta$ diversity, illustrating the variability in species composition of drifting insects in urban and rural streams.

Shannon-Wiener diversity (Figure 2C) was higher in the rural stream. However, no significant differences were observed between streams.

\section{Discussion}

Lotic environments respond not only to local impacts, but reflect the consequences of human activities developed in their surroundings. Thus, the distribution of organisms in aquatic habitats is generally regulated by several factors, mainly the tolerance to physical and chemical conditions of the water (Cummins and Klug, 1979). As expected, in the present study, species composition differed significantly between streams. Moreover, as predicted, higher diversity of drifting insects was observed in the rural stream and higher abundance in the urban stream, due to changes in physical and chemical variables of the water. However, the differences observed in these ecological attributes were not significant, and thus the hypothesis was not confirmed. The results demonstrate that physical and chemical characteristics of the water are different between urban and rural streams. Consequently, the insect community responded to these differences and the species composition, diversity and abundance differed between streams. Some studies have reported that there are effects on species composition in urban areas relative to rural, with increasing dominance of mainly generalist and opportunist species in urban areas (Magura et al., 2008; Jones and Leather, 2012). The results of PERMIDISP evidenced a significant change in species composition between streams, besides the record of species that only occurred in each stream.

This difference is due to the predominance of tolerant species (considered generalist and/or opportunist) in the urban stream, especially species of Chironomidae, at the expense of sensitive species (specialists), particularly EPT and Coleoptera taxa, which disappears or become rare in these environments, but were present in the rural stream (see Table 2). Furthermore, according to Millán et al. (2011), local impacts may increase the heterogeneity of the ecosystem and consequently, the beta diversity. The effect
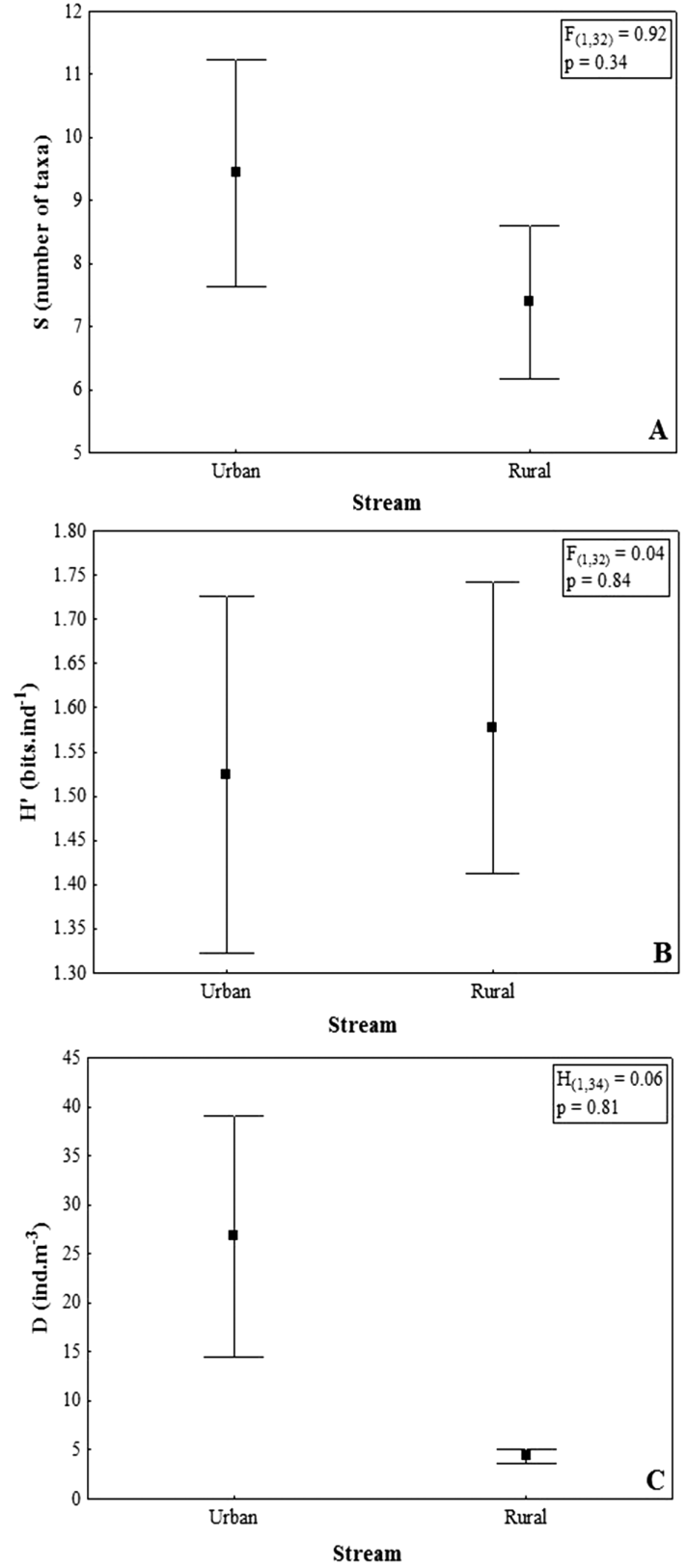

Figure 2. Mean values and standard error of richness (A) Shannon-Wiener diversity; (B) and density; (C) in urban and rural streams.

of environmental heterogeneity on the species composition (tolerant and sensitive) in urban and rural streams, may have been important to increase beta diversity in the stream subjected to local environmental impacts (urban stream).

The highest number of taxa (39), as well as higher diversity, observed in the rural stream, can be directly related to the land use. Despite being affected by agricultural effluents, since it is located in a rural area, this stream is under less human influence, regarding the impact of domestic and industrial organic wastes, which influenced 
the determination of such attributes. Similarly, Wilhm (1967), in a classic study, found that benthic diversity was reduced for more than $96 \mathrm{~km}$ downstream in a stream receiving improperly treated municipal sewage.

Insects of the orders Ephemeroptera, Plecoptera and Trichoptera (EPT) are generally sensitive to environmental disturbances and usually live mainly in clean and well oxygenated waters (Buss et al., 2004; Bispo et al., 2006). Due to these characteristics, this fauna is commonly considered as a good indicator of water quality (Rosenberg and Resh, 1993). The sensitivity of some species of this group may explain the highest species richness of Ephemeroptera and Trichoptera, beyond the exclusive occurrence of Anacroneuria ofaye (Plecoptera), in the rural stream, which showed high levels of dissolved oxygen and high flow.

Barbour et al. (1996) further noticed that both the number of Coleoptera and EPT taxa decreased with increasing disturbance. Therefore, some studies have added Coleoptera to the standard EPT index. Indeed, Coleoptera are an important component of stream invertebrate assemblages (Cayrou et al., 2000), and contains sensitive taxa particularly in the family Elmidae, therefore, considering the four insect orders might enhance the accuracy of water quality assessments (Compin and Céréghino, 2003). Our study confirmed the above, since some species of Coleoptera, especially of the Elmidae family, occurred exclusively in the rural stream, confirming their sensitivity to the processes of urbanization.

Although the reduced diversity of drifting insects, the mean richness was higher in the urban stream, where there was an increase in the number of taxa, mainly due to the species of the family Chironomidae, which was also accompanied by an increase in their abundance. Moreover, in the urban stream we found higher values of electrical conductivity, probably due to a higher impervious surface of this stream, since paved areas can, among other factors, retain solar energy and solid wastes (Theobald et al., 2009; Fogaça et al., 2013) that are carried to the streams after rainfall events. The conductivity influences the distribution of invertebrate fauna only at extreme values or when associated with organic pollution (Bispo et al., 2006).

Increased electrical conductivity, in association with organic pollution (which might have caused high levels of nitrogen) and combined with high $\mathrm{pH}$ values, possibly has promoted an increase in the abundance of Chironomidae larvae in the urban stream (that might be interpreted as catastrophic drift), mainly Polypedilum sp. 4, the species with the highest density in this stream. This is related to the ability of this family in exploring a wide range of trophic conditions in aquatic ecosystems, mainly due to their high capacity of physiological adaptation, which allows individuals to live in habitats with variable environmental conditions (Entrekin et al., 2007). Furthermore, larvae of the genus Polypedilum and some other genera, such as Chironomus, which was also recorded in the urban stream, may exhibit tolerance to organic pollution and have long been recognized as indicators of heavy organic pollution in lotic ecosystems, and therefore have been found in impacted lotic environments in other studies (Coimbra et al., 1996; Bazzanti, 2000; Helson et al., 2006).

Therefore, the results showed that abundance and diversity of drifting insects was not different between urban and rural streams. On the other hand, the species composition proved to be a good predictor of different impacts in streams, and the measure of beta diversity can express the degradation process, as indicated by the results of this study.

\section{Acknowledgements}

We acknowledge the field team for assisting with collections, MCT/CNPq/CT-Hidro (Proc. 555185/2006-0) for funding the project and Nupélia for logistical support. The first author would like to thank the Brazilian Coordination for the Improvement of Higher Education Personnel (CAPES) for the scholarship.

\section{References}

ALLAN, J.D., 2004. Landscapes and riverscapes: the influence of land use on stream ecosystems. Annual Review of Ecology Evolution and Systematics, vol. 35, no. 1, pp. 257-284. http:// dx.doi.org/10.1146/annurev.ecolsys.35.120202.110122.

ANDERSON, M.J., ELLINGSEN, K.E. and MCARDLE, B.H., 2006. Multivariate dispersion as a measure of beta diversity. Ecology Letters, vol. 9, no. 6, pp. 683-693. http://dx.doi.org/10.1111/j.14610248.2006.00926.x. PMid:16706913.

BARBOUR, M.T., GERRITSEN, J., GRIFFITH, G.E., FRYDENBORG, R., MCCARRON, E., WHITE, J.S. and BASTIAN, M.L., 1996. A framework for biological criteria for Florida streams using benthic macroinvertebrates. Journal of the North American Benthological Society, vol. 15, no. 2, pp. 185-211. http://dx.doi.org/10.2307/1467948.

BAZZANTI, M., 2000. Ecological requirements of chironomids (Diptera: Chironomidae) on the soft bottom of the River Arrone, Central Italy. Journal of Freshwater Ecology, vol. 15, no. 3, pp. 397-409. http://dx.doi.org/10.1080/02705060.2000.9663758.

BISPO, P.C., OLIVEIRA, L.G., BINI, L.M. and SOUSA, K.G., 2006. Ephemeroptera, Plecoptera and Trichoptera assemblages from riffles in mountain streams of Central Brazil: environmental factors influencing the distribution and abundance of immatures. Brazilian Journal of Biology = Revista Brasileira de Biologia, vol. 66, no. 2B, pp. 611-622. http://dx.doi.org/10.1590/S151969842006000400005. PMid:16906293.

BRITTAIN, J.E. and EIKELAND, T.J., 1988. Invertebrate drift: a review. Hydrobiologia, vol. 166, no. 1, pp. 77-93. http://dx.doi. org/10.1007/BF00017485.

BUSS, D.F., BAPTISTA, D.F., NESSIMIAN, J.L. and EGLER, M., 2004. Substrate specifity, environmental degradation and disturbance structuring macroinvertebrate assemblages in neotropical streams. Hydrobiologia, vol. 518, no. 1-3, pp. 179188. http://dx.doi.org/10.1023/B:HYDR.0000025067.66126.1c.

CALLISTO, M. and GOULART, M., 2005. Invertebrate drift along a longitudinal gradient in a Neotropical stream in Serra do Cipó National Park, Brazil. Hydrobiologia, vol. 539, no. 1, pp. 47-56. http://dx.doi.org/10.1007/s10750-004-3245-4. 
CALLISTO, M., GOULART, M., BARBOSA, F.A.R. and ROCHA, O., 2005. Biodiversity assessment of benthic macroinvertebrates along a reservoir cascade in the lower São Francisco River (Northeastern Brazil). Brazilian Journal of Biology $=$ Revista Brasileira de Biologia, vol. 65, no. 2, pp. 229-240. http://dx.doi. org/10.1590/S1519-69842005000200006. PMid:16097725.

CASTRO, D.M.P., HUGHES, R.M. and CALLISTO, M., 2013. Influence of peak flow changes on the macroinvertebrate drift downstream of a Brazilian hydroelectric dam. Brazilian Journal of Biology $=$ Revista Brasileira de Biologia, vol. 73, no. 4, pp. 775-782. http://dx.doi.org/10.1590/S1519-69842013000400013. PMid:24789393.

CAYROU, J., COMPIN, A., GIANI, N. and CÉRÉGHINO, R., 2000. Associations spécifiques chez les macroinvertébrés benthiques et leur utilisation pour la classification des cours d'eau. Cas du réseau hydrographique Adour-Garonne (France). Annales de Limnologie, vol. 36, no. 3, pp. 189-202. http://dx.doi. org/10.1051/limn/2000017.

COIMBRA, C.N., GRAÇA, M.A. and CORTES, R.M., 1996. The effects of a basic effluent on macroinvertebrate community structure in a temporary Mediterranean river. Environmental Pollution, vol. 94, no. 3, pp. 301-307. http://dx.doi.org/10.1016/ S0269-7491(96)00091-7. PMid:15093490.

COMPIN, A. and CÉRÉGHINO, R., 2003. Sensitivity of aquatic insect species richness to disturbance in the Adour-Garonne stream system (France). Ecological Indicators, vol. 3, no. 2, pp. 135-142. http://dx.doi.org/10.1016/S1470-160X(03)00016-5.

CUMMINS, K.W. and KLUG, M.J., 1979. Feeding ecology of stream invertebrates. Annual Review of Ecology and Systematics, vol. 10, no. 1, pp. 147-172. http://dx.doi.org/10.1146/annurev. es.10.110179.001051.

CUNICO, A.M., FERREIRA, E.A., AGOSTINHO, A.A., BEAUMORD, A.C. and FERNANDES, R., 2012. The effects of local and regional environmental factors on the structure of fish assemblages in the Pirapó Basin, Southern Brazil. Landscape and Urban Planning, vol. 105, no. 3, pp. 336-344. http://dx.doi. org/10.1016/j.landurbplan.2012.01.002.

ELLIOTT, J.M., 2008. Ontogenetic shifts in drift periodicity and benthic dispersal in elmid beetles. Freshwater Biology, vol. 53, no. 4, pp. 698-713. http://dx.doi.org/10.1111/j.1365-2427.2007.01927.x.

ENTREKIN, S.A., WALLACE, J.B. and EGGERT, S.L., 2007. The response of Chironomidae (Diptera) to a long-term exclusion of terrestrial organic matter. Hydrobiologia, vol. 575, no. 1, pp. 401-413. http://dx.doi.org/10.1007/s10750-006-0386-7.

FOGAÇA, F.N.O., GOMES, L.C. and HIGUTI, J., 2013. Percentage of impervious surface soil as indicator of urbanization impacts in Neotropical aquatic insects. Neotropical Entomology, vol. 42, no. 5, pp. 483-491. http://dx.doi.org/10.1007/s13744-013-0155-z. PMid:23949987.

HANSEN, E.A. and CLOSS, G.P., 2007. Temporal consistencyin the long-term spatial distribution of macroinvertebrate drift along a stream reach. Hydrobiologia, vol. 575, no. 1, pp. 361-371. http:// dx.doi.org/10.1007/s10750-006-0384-9.

HAUER, F.R. and LAMBERTI, G.A., 2007. Methods in stream ecology. 2nd ed. London: Academic Press. 896 p.

HELSON, J.E., WILLIAMS, D.D. and TURNER, D., 2006. Larval chironomid community organization in four tropical rivers: human impacts and longitudinal zonation. Hydrobiologia, vol. 559, no. 1, pp. 413-431. http://dx.doi.org/10.1007/s10750-005-0977-8.
INSTITUTO BRASILEIRO DE GEOGRAFIA E ESTATÍSTICA - IBGE, 2010 [viewed 01 March 2015]. Cidades 2010: Maringá [online]. Available from: http://cidades.ibge.gov.br/xtras/perfil.ph $\mathrm{p}$ ?lang $=\&$ codmun $=411520 \&$ search $=$ parana $\mid$ maringa

JONES, E.L. and LEATHER, S.R., 2012. Invertebrates in urban areas: a review. European Journal of Entomology, vol. 109, no. 4, pp. 463-478. http://dx.doi.org/10.14411/eje.2012.060.

JÚLIO-JÚNIOR, H.F., THOMAZ, S.M., AGOSTINHO, A.A. and LATINI, J.D., 2005. Distribuição e caracterização dos reservatórios. In: L. RODRIGUES, S.M. THOMAZ, A.A. AGOSTINHO and L.C. GOMES. Biocenoses em reservatórios: padrões espaciais e temporais. Maringá: Eduem, pp. 1-16.

KINDT, R. and COE, R., 2005. Tree diversity analysis: a manual and software for common statistical methods for ecological and biodiversity studies. Nairobi: World Agroforestry Centre.

KUHL, A.M., ROCHA, C.L.M.S.C., ESPÍNDOLA, E.L.G. and LANSAC-TÔHA, F.A., 2010. Rural and urban streams: anthropogenic influences and impacts on water and sediment quality. International Review of Hydrobiology, vol. 95, no. 3, pp. 260-272. http://dx.doi.org/10.1002/iroh.200911190.

MAGURA, T., LÖVEI, G.L. and TÓTHMÉRÉSZ, B., 2008. Time-consistent rearrangement of carabid beetle assemblages by an urbanisation gradient in Hungary. Acta Oecologica, vol. 34, no. 2, pp. 233-243. http://dx.doi.org/10.1016/j.actao.2008.05.010.

MAGURRAN, A.E., 1988. Ecological diversity and its measurement. New Jersey: Princeton University. 197 p. http:// dx.doi.org/10.1007/978-94-015-7358-0.

MEYER, J.L., PAUL, M.J. and TAULBEE, W.K., 2005. Stream ecosystem function in urbanizing landscapes. Journal of the North American Benthological Society, vol. 24, no. 3, pp. 602-612. http:// dx.doi.org/10.1899/0887-3593(2005)0240602:SEFIUL2.0.CO;2.

MILLÁN, A., VELASCO, J., GUTIÉRREZ-CÁNOVAS, C., ARRIBAS, P., PICAZO, F., SÁNCHEZ-FERNÁNDEZ, D. and ABELLÁN, P., 2011. Mediterranean saline streams in southeast Spain: what do we know? Journal of Arid Environments, vol. 75, no. 12, pp. 1352-1359. http://dx.doi.org/10.1016/j.jaridenv.2010.12.010.

MORENO, P., FRANÇA, J.S., FERREIRA, W.R., PAZ, A.D., MONTEIRO, I.M. and CALLISTO, M., 2009. Use of the BEAST model for biomonitoring water quality in a neotropical basin. Hydrobiologia, vol. 630, no. 1, pp. 231-242. http://dx.doi. org/10.1007/s10750-009-9796-7.

NOVAES, M.C., BISPO, P.C. and HIGUTI, J., 2012. A description of the nymph of Anacroneuria ofaye Froehlich (Plecoptera: Perlidae) and a apparatus for rearing Neotropical stonefly species. Zootaxa, vol. 3547, pp. 71-77.

OKSANEN, J., BLANCHET, F.G., KINDT, R., LEGENDRE, P., MINCHIN, P.R., O'HARA, R.B., SIMPSON, G.L. and SOLYMOS, P., STEVENS, M.H.H. and WAGNER, H., 2013 [viewed 01 March 2015] Vegan: community ecology package. R package version 2.0-8 [software]. Available from: http://CRAN.R-project. org $/$ package $=$ vegan

PES, A.M.O., HAMADA, N. and NESSIMIAN, J.L., 2005. Chave de identificação de larvas para famílias e gêneros de Trichoptera (Insecta) da Amazônia Central, Brasil. Revista Brasileira de Entomologia, vol. 49, no. 2, pp. 181-204. http://dx.doi.org/10.1590/ S0085-56262005000200002.

PRINCIPE, R.E. and CORIGLIANO, M.C., 2006. Benthic, drifting and marginal macroinvertebrate assemblages in a lowland river: temporal and spatial variations and size structure. Hydrobiologia, 
vol. 553, no. 1, pp. 303-317. http://dx.doi.org/10.1007/s10750005-0694-3.

R DEVELOPMENT CORE TEAM, 2008. $R$ : a language and environment for statistical computing [software]. Vienna: $\mathrm{R}$ Foundation for Statistical Computing.

RESH, V.H. and ROSENBERG, D.M., 1984. The ecology of aquatic insects. New York: Praeger Publishers. 625 p.

ROSENBERG, D.M. and RESH, V.H., 1993. Freshwater biomonitoring and benthic macroinvertebrates. London: Chapman and Hall. 488 p.

SALLES, F.F., 2006. A ordem Ephemeroptera no Brasil (Insecta): taxonomia e diversidade. Viçosa: Universidade Federal de Viçosa, 300 p. Tese de Doutorado em Entomologia.

SANEPAR, 2002. Plano de gestão e manejo do manancial do rio Pirapó, Maringá - PR. Maringá: Companhia de Saneamento do Paraná. 53 p.

SAULINO, H.H.L., CORBI, J.J. and TRIVINHO-STRIXINO, S., 2014. Aquatic insect community structure under the influence of small dams in a stream of the Mogi-Guaçu river basin, state of São Paulo. Brazilian Journal of Biology $=$ Revista Brasileira de Biologia, vol. 74, no. 1, pp. 79-88. http://dx.doi.org/10.1590/15196984.17512. PMid:25055089.

STATSOFT INC, 2005 [viewed 01 March 2015] Statistica (data analysis software system). Version 7.1 [software]. Available from: www.statisoft.inc.
THEOBALD, D.M., GOETZ, S.J., NORMAN, J.B. and JANTZ, P., 2009. Watersheds at risk to increased impervious surface cover in the conterminous United States. Journal of Hydrologic Engineering, vol. 14, no. 4, pp. 362-368. http://dx.doi.org/10.1061/ (ASCE)1084-0699(2009)14:4(362).

TRIVINHO-STRIXINO, S., 2011. Larvas de Chironomidae: guia de identificação. São Carlos: UFSCar. 371 p.

VANNOTE, L.R., MINSHALL, G.W., CUMMINS, K.W., SEDELL, J.R. and CUSHING, C.E., 1980. The river continuum concept. Canadian Journal of Fisheries and Aquatic Sciences, vol. 37, no. 1, pp. 130-137. http://dx.doi.org/10.1139/f80-017.

WARD, D., HOLMES, N. and JOSÉ, P., 1995. The new rivers \& wildlife handbook. Bedfordshire: The Wildlife Trusts. $426 \mathrm{p}$.

WATERS, T.F., 1965. Interpretation of invertebrate drift in streams. Ecology, vol. 46, no. 3, pp. 327-334. http://dx.doi. org/10.2307/1936336.

WATERS, T.F., 1972. The drift of stream insects. Annual Review of Entomology, vol. 17, no. 1, pp. 253-272. http://dx.doi.org/10.1146/ annurev.en.17.010172.001345.

WILHM, J.L., 1967. Comparison of some diversity indices apllied to populations of benthic macroinvertebrates in a stream receiving organic wastes. Journal - Water Pollution Control Federation, vol. 39 , pp. 1673-1683. 